\title{
MOTIVATION DRIVERS AND BARRIERS OF GENERATION Z AT WORK: MEBS METHOD
}

\author{
Jiř́i Kutlák
}

\begin{abstract}
Generation Z, the youngest economically active generation in the labour markets, is currently entering its professional life. As with previous generations, representatives of the generation $\mathrm{Z}$ (1995-2010) are typical for their characteristics, attitudes or requirements. For companies, the task then arises in the form of identification of these motivational, but also demotivational factors, for effective management and motivation of their employees. The aim of the study is an identification and mutual comparison of motivational factors and barriers in the conditions of the Czech Republic. The research is carried out using the method of empathy-based stories (MEBS), which is based on short fictional stories and works with empathy of the respondents. The research sample consists of 134 respondents who identified a total of 481 items of motivation drivers and 496 items of motivation barriers, which are part of 5 clusters. According to the results, it is clear that the factors include the relationship with co-workers and the atmosphere in the workplace, remuneration and meaningful job. On the contrary, the factors with the least influence can include work-life balance or job security, for which, however, the influence of the structure of the research sample, which consists of university students, is possible. Regarding clusters, the areas of Relationships at work and Work-related factors have the largest share (importance). On the contrary, the least importance is given to the areas of Achievement (Career and Learning) and Out of work (personal) factors. A significant agreement of de / motivational factors was discovered in an international comparison with research based on the same method of data collection.
\end{abstract}

Keywords: Generation Z, MEBS method, work motivation, motivation barriers

\section{INTRODUCTION}

At present, two major tendencies can be observed in the vast majority of Central European labour markets, which influence the formation and behaviour of the labour force on the supply side and enterprises on the demand side. One of the elements is low unemployment, which is a consequence of the economic boom period. At the end of the year, the unemployment rate of the European Union was slightly over 6\%, in selected Central European countries the rate was even well below this threshold (Czech Republic 2\%; Germany 3\%; Slovakia 5\%; Poland $\sim 3 \%$ ) (Eurostat, 2020). Such a low level of the labour market represents a fundamental problem for companies in times of economic growth in recruiting and maintaining a workforce. The HR departments of organizations are thus often forced to pay more and more attention to the quality and efficiency of personnel processes.

The second tendency that can be traced in the labour market is the natural movement of the labour force, which is characterized by changes in the number of people of working age (15-64 years). This trend also applies to the Czech Republic, where will be according to Němečková (2019) the decrease in people of working age in the next 30 years by up to about 1 million people (out of the current 6.9 million people). The data show that the older age generations are gradually leaving the labour markets and are only partially replaced by the younger generations. In addition to the aforementioned Czech Republic, this trend is also evident in the surrounding countries - Slovakia, Hungary or Poland. Moreover, the states forming the so-called Visegrad 
group are also very similar to the relative representation of individual generations in their population. However, in contrast to the United States, the proportion of the youngest generations $\mathrm{Y}$ and $\mathrm{Z}$ is not so high in comparison, which contributes to the gradual decline of people of working age over the following years (Mičík et al., 2020).

It is very important for organizations to adapt to gradual changes in labour markets, which are influenced, among other things, by the characteristics and attitudes of the individual generations that make up the labour market. The youngest generation entering the labour market is the generation Z (Gen Z), whose annual anchorage is 1995-2010 (Bencsik, Juhász \& HorváthCsikós, 2016; Issa \& Isaias, 2016; Koulopoulos \& Keldsen, 2016). It is the knowledge of this new workforce and the adaptation of processes that is the challenge for companies in the coming years. The aim of the paper is to identify the perception of motivational and demotivational factors by representatives of the $\mathrm{Z}$ generation in the conditions of the Czech Republic and the subsequent international comparison of these findings.

The paper is organized as follows. First, attitudes and characteristics of the generation $\mathrm{Z}$ are described. Next, the method and the research instrument are explained. Then, the study results are report and discuss. Finally, the conclusions and limitations of the study are provided.

\section{THEORETICAL BACKGROUND}

Generation $\mathrm{Z}$ grew up as the first generation in a completely globalized and interconnected world, dominated primarily by information and communication technologies (ICT). Despite the fact that the previous generation of Millennials met ICT in their childhood, generation Z grows up with them from birth and is therefore often called Net Gen, iGen, Digital Natives or Generation C (connected, communicating, etc.) (Baldonado, 2018; Friedrich et al., 2010). Three-quarters of generation $\mathrm{Z}$ representatives according to Cision (2013) agree that the relationship and experience in the field of technology help them achieve the desired goal. At the same time, about half of the Gen Z surveyed in the Deloitte survey (Gomez, Mawhinney \& Betts, 2018) rated the technology industry as the best for the job. This fact has also a dark side, $40 \%$ admitted that they felt to be digitally dependent (Monych, 2017). On the contrary, a positive impact is evident in the area of multitasking. The use of a wide range of devices (visual, auditory, tactile) has ensured that Gen $\mathrm{Z}$ has developed the ability to synchronize hands, eyes and ears most in existing human history (Berkup, 2014).

In addition to technology, the formation of this generation also influenced economic and social events, which can include the economic crisis of 2008 (Gomez, Mawhinney \& Betts, 2018). This is also reflected in an upbringing, which focuses more on preparing an individual for adult life - independence and responsibility. Parents try to explain things to their children in wider consequences, try increase a communication with children and transfer more responsibility and worries to them. This is confirmed, for example, by the fact that $93 \%$ of parents reported that their Gen $\mathrm{Z}$ children had an impact on the determination of family expenses. In particular, $65 \%$ reported that children influence holiday choice and $32 \%$ of parents acknowledged that children's opinion affected the purchase of apartment equipment (Merriman, 2015). Here may be mentioned the difference between Gen $\mathrm{Z}$ and older Millennials, for which parents are guardians and constant supporters (including financial support). Millennials expect this form of protection and support from their parents also in adulthood. For example, after graduating from college - roughly one in four at the age of 25-34 lives still with their parents (Merriman, 2015).

Regarding the most important work motivation factors, research agrees mainly on three factors: financial security, career opportunities and meaningful job (Gomez, Mawhinney \& Betts, 2018; Half, 2015; Wiedmer, 2015; Schawbel, 2014). Career opportunities are also associated with the 
area of employee development, which is gaining in importance due to the fact that generation $\mathrm{Z}$ is becoming the most educated generation ever (Adecco, 2019).

Other factors include the need for flexibility, with which, according to ManpowerGroup (2016), companies can ensure the retention of young talent. Sidorcuka and Chesnoviska (2017) also identified with this, according to whose research the flexibility of time and work belongs to the requirements of employees that should be respected. The need for time flexibility is also related to the fact that Gen Z is ready to break the boundaries between work and leisure (Henley, 2019).

Regarding the expectations of employers from the Z generation, Kutlák (2020) in his research came to the following facts, which are more in line with those described above. According to employers, the main motivational factors of the generation $\mathrm{Z}$ include: Flexibility of working hours; Rewarding, Meaningful job; work-life-balance or Attractive workplace culture. As for the clusters themselves, the highest rated areas were Learning and Career Development and Social and Corporate Atmosphere.

\section{METHODOLOGY}

The research framework is based on studies according to Kultalahti and Viital (2014) or Fratričová and Kirchmayer (2018a). Studies are focused on the identification of work motivation and demotivation factors according to generation $\mathrm{Y}$ in Finland and generation $\mathrm{Z}$ in Slovakia. The aim of this qualitative research is to collect and identify factors that positively and negatively affect the motivation of representatives of the generation $\mathrm{Z}$ in the Czech Republic. Specifically, these are students of the Faculty of Economics in Pilsen, who were born between the years 1995-2010. Despite the fact that the sample of respondents is very narrow and not large (134 valid answers), for mutual international comparison of the resulting data with previous research, especially with research according to Fratričová and Kirchmayer $(2018 \mathrm{a}, \mathrm{b})$, the sociodemographic sample data are very appropriate.

For the purposes of this article, the following research questions have been established: What factors and areas motivate generation $\mathrm{Z}$ representatives in the work environment? What factors and areas demotivate representatives of the $\mathrm{Z}$ generation in the work environment?

The above research questions are asked at the present tense, despite the fact that most respondents are not fully involved in professional life. However, only 13 respondents had no experience with a paid job or internship in the last six months. It should be noted that full-time work is often associated with other social milestones (own housing, starting a family, etc.) and can influence the thinking of respondents. At the same time, the present tense was used due to the method of data collection used. The method of empathy-based stories (MEBS) was used for research purposes.

The MEBS method is one of the qualitative methods of data collection and is similar in content to the fictional narrative role-playing method. The method began to be used more frequently in the 1980s in Finland and is now used worldwide for various sciences (Wallin, Koro-Ljungberg \& Eskola, 2019; Posti-Ahokas, 2013; Eskola, 1991). The MEBS method is based on writing short fictional stories, which are formed on an introductory story forwarded by the author of the research himself. An introductory story is a brief presentation of an event or situation to which respondents respond or complete. The method is based on the expectation that the research participants empathize with the story and therefore respond based on their own beliefs. The method according to Gerace et al. (2013) also works with elements of the empathic process including the concepts of emotional empathy, personal anxiety, sympathy or antipathy. As mentioned by Wallin, Koro-Ljungberg and Eskola (2019), in the MEBS method we rather encounter applied empathy, which does not necessarily require empathic feelings. 
Respondents were presented with 2 stories, one of which was positive and the other was negative. The aim of a positive story is to identify motivational factors in the work environment. The negative story focused on barriers of motivation in the work environment. The stories were based on research by Fratričová and Kirchmayer (2018a, b), and Kultalahti and Viitala (2014), while it was translated into Czech and one of the typical Czech names Vlasta was added to the story for easier identification with the presented story. The wording of the name in the Czech language is also gender neutral and allows both sexes to have the same level of empathy.

Positive story: Imagine that Vlasta returns from work one day. He feels motivated and has a lot of energy for further work. He doesn't mind getting up to work, he is even always looking forward to the next working day. What is behind the fact that Vlasta feels so motivated and so excited about his work?

Negative story: Imagine that Vlasta returns from work one day. He feels tired and has no enthusiasm for further work. Vlasta is not looking forward to the morning when he has to get up to work again. The only thing he looks forward to is a free weekend. What is behind the fact that Vlasta feels so demotivated from his work and why does he lack enthusiasm?

For the purposes of this research, the distribution of data through online forms was used. This method is no obstacle for the representatives of the generation $\mathrm{Z}$, otherwise known as the Internet generation. The questionnaires were distributed among students of the University of West Bohemia in Pilsen, Faculty of Economics. A total of 134 respondents with births from 1995-2002 took part in the survey. Respondents with the year of birth in 1998 (41\%) had the largest representation, followed by the year of birth in 1999 (34\%) and 1997 (11\%). All respondents answered both stories. The answers were recorded in the form of a list of items or in the form of a continuous text. The results were subjected to content analysis, which can be described as a subjective interpretation of the content of textual data through a systematic sorting process of coding and identification of topics or patterns (Hsieh \& Shannon, 2005).

Factors and clusters according to Fratričová \& Kirchmayer $(2018 \mathrm{a}, \mathrm{b})$ were used to code the answers from the content analysis. Based on the coding in the content analysis, 481 factors were obtained for the positive story and 496 factors for the negative story. On average, less than 4 factors were decoded for each respondent for each of the stories. Using content analysis as described above, 23 positive factors and 26 negative factors were saturated with at least one response. These factors are based on the factor clusters model below, which consists of 3 main pillars (Employee, Job and Organization) and 5 clusters are based on them.

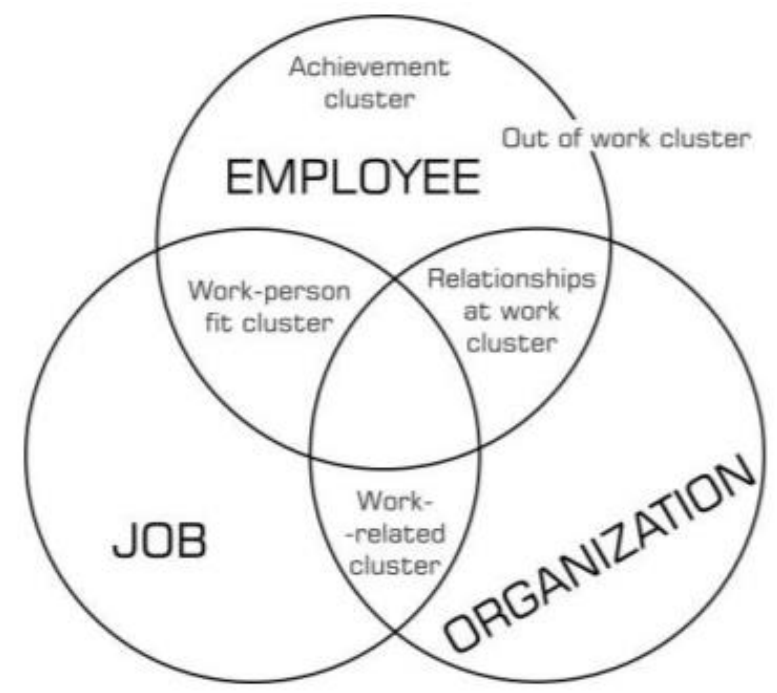

Fig. 1 - Model of clusters. Source: Fratričová \& Kirchmayer (2018a, b) 


\section{RESULTS}

The results of the comparison of the clusters themselves (see Table 1) indicate that in both analysed stories, the "Relationships at work, Work, Work-person" belong to the most mentioned clusters. These three areas make up about $85-90 \%$ for both stories. The minor parts then form clusters Achievement and Out of work factors.

Tab. 1 - Clusters ranking by relative share. Source: own research

\begin{tabular}{|l|c|c|}
\hline \multirow{2}{*}{ Cluster } & \multicolumn{2}{|c|}{$\%$ of items } \\
\cline { 2 - 3 } & Positive & Negative \\
\hline Relationships at work & $28 \%$ & $37 \%$ \\
\hline Work & $28 \%$ & $28 \%$ \\
\hline Work-person & $28 \%$ & $24 \%$ \\
\hline Achievement & $12 \%$ & $7 \%$ \\
\hline Out of work & $4 \%$ & $5 \%$ \\
\hline
\end{tabular}

The area of workplace relations is one of the most mentioned in both stories. The positive story was mainly about answers focusing on a good work team. At the same time, this answer was the most frequently mentioned factor - 78\% (see Table 2). Another factor in Vlasta's employee motivation was the leadership factor. Respondents consider this cluster with $37 \%$ to be a fundamental barrier to the Vlasta's motivation. In the answers, factors related to the work team $(61 \%)$ and relationships with the superior $(30 \%)$ were most often marked (similarly to the positive story). At the same time, factors in the form of conflicts with co-workers or bullying were mentioned in $19 \%$ of respondents.

The cluster focusing on work factors is comparable in the relative number of mentioned factors in both analysed stories (equally $28 \%$ ). In the case of a positive story, the most frequent answer with $55 \%$ was the area of wage remuneration, specifically in the form of wage increases or the award of bonuses. $45 \%$ of respondents included low / inadequate wages as barriers to motivation for a negative story. A total of $28 \%$ of respondents also mentioned the issue of a large number of tasks and their possible complexity, $16 \%$ consider the appearance or equipment of the workplace to be a barrier to motivation.

The third most frequently mentioned area is the cluster focusing on the work-person relationship. 57\% of respondents cited the reason for Vlasta's positive emotions by the fact that he enjoys and likes the work he or she does. In second place, the factor expressing the fact that the worker performs work that interests him and whose content fills him, placed with $18 \%$. On the contrary, according to the respondents, the factor that contributes to demotivation is the content of the work performed (39\%). Other barriers to motivation were identified as the meaning of the work performed (19\%) and the lack of autonomy at work (16\%).

In the achievement cluster, 3 factors were identified in the positive story of Vlasta's employee: Achievement; Recognition and Career advancement. The evaluation of all the above factors is very identical, between $12-17 \%$. Inverse factors were also identified in the second story, namely Poor performance, Career stagnation and Lack of recognition. Factors were mentioned in answers by about $7-10 \%$ of respondents. It is the lower incidence in responses to barriers of motivation that affects the overall share of this cluster $(7 \%)$, in contrast to the $12 \%$ share in the inter-cluster comparison of the positive story of the employee Vlasta.

Almost the same share (4-5\%) for both stories belong to the areas of factors marked out of work, which are related to the employee, but not in direct relation to the work or the company. In both stories, these are answers that indicate the employee's de / motivation, which stems from personal life (health, family, friends) or is the result of the current distribution (physiological factors). 
Table 2 below lists the 10 most frequently mentioned de/motivational factors from both analysed stories. At the same time, the outlined answers outlined are inverse to each other, so they were identified as both a motivational and a demotivational factor, of course due to the opposite meaning (e.g. high / low wage). These factors can be identified as very important, as they evoke both positive and negative emotions in the respondents.

Tab. 2 - Clusters ranking by relative share. Source: own research

\begin{tabular}{|c|c|c|c|c|c|}
\hline \multicolumn{3}{|c|}{ Motivational factors (positive story) } & \multicolumn{3}{|c|}{ Demotivational factors (negative story) } \\
\hline Factor & $\begin{array}{c}\text { Nominal item } \\
\text { prevalence }\end{array}$ & $\begin{array}{c}\% \text { of respondents } \\
(\mathrm{N}=134)\end{array}$ & Factor & $\begin{array}{c}\text { Nominal item } \\
\text { prevalence }\end{array}$ & $\begin{array}{c}\% \text { of respondents } \\
(\mathrm{N}=134)\end{array}$ \\
\hline Co-workers & 104 & 78 & $\begin{array}{l}\text { Co-workers: } \\
\text { Team climate }\end{array}$ & 82 & 61 \\
\hline Meaningful job & 77 & 57 & Reward & 60 & 45 \\
\hline Reward & 74 & 55 & $\begin{array}{l}\text { Does not enjoy } \\
\text { his work }\end{array}$ & 52 & 39 \\
\hline Leadership & 30 & 22 & $\begin{array}{l}\text { Leadership: } \\
\text { Relationship }\end{array}$ & 40 & 30 \\
\hline $\begin{array}{l}\text { Work of } \\
\text { interest }\end{array}$ & 24 & 18 & $\begin{array}{l}\text { Leadership: } \\
\text { Bad leader }\end{array}$ & 29 & 22 \\
\hline Achievement & 23 & 17 & $\begin{array}{l}\text { Lack of sense } \\
\text { of purpose }\end{array}$ & 25 & 19 \\
\hline Workplace & 22 & 16 & Workload & 24 & 18 \\
\hline Recognition & 20 & 15 & $\begin{array}{l}\text { Lack of } \\
\text { autonomy }\end{array}$ & 21 & 16 \\
\hline Impact & 18 & 13 & $\begin{array}{l}\text { Co-workers: } \\
\text { Conflicts } \\
\end{array}$ & 19 & 14 \\
\hline $\begin{array}{l}\text { Career } \\
\text { advancement }\end{array}$ & 16 & 12 & $\begin{array}{l}\text { No interest in } \\
\text { work }\end{array}$ & 15 & 11 \\
\hline $\begin{array}{l}\text { Remaining } \\
\text { factors }\end{array}$ & 63 & $<6$ each item & $\begin{array}{l}\text { Remaining } \\
\text { factors }\end{array}$ & 129 & $<11$ each item \\
\hline
\end{tabular}

\section{International comparison}

The comparison of the outputs from the content analysis with the research of Fratričová \& Kirchmayer $(2018 \mathrm{a}, \mathrm{b})$ applying the same method to a very similar sample of respondents (university students - Faculty of Economics) is shown in Table 3 below. There are noticeable differences in motivating elements, especially in the issue of workplace relations and the issue of achievement. Differences in demotivational factors also apply to the same areas. In addition, greater differences can be observed in demotivational factors also in the area of Work-person.

Tab. 3 - Clusters ranking in selected countries. Source: own research; Fratričová \& Kirchmayer (2018a, b)

\begin{tabular}{|l|c|c||c|c|}
\hline \multirow{2}{*}{ Clusters } & \multicolumn{2}{|c||}{ CZE } & \multicolumn{2}{c|}{ SVK } \\
\cline { 2 - 5 } & \multicolumn{2}{|c|}{ \% of items } & \multicolumn{2}{c|}{ \% of items } \\
\cline { 2 - 5 } & Positive & Negative & Positive & Negative \\
\hline Relationships at work & 28 & 37 & 16 & 26 \\
\hline Work & 28 & 28 & 24 & 24 \\
\hline Work-person & 28 & 24 & 29 & 37 \\
\hline Achievement & 12 & 7 & 20 & 9 \\
\hline Out of work & 4 & 5 & 7 & 4 \\
\hline
\end{tabular}

When comparing specific factors, it can be identified that in both countries, the biggest de / motivational factors are Co-workers, Meaningful work and Reward. Significantly higher shares 
within the motivational factors were achieved in Slovak research by items related to personal and career development. On the contrary, Czech respondents more often mention the issue of meaningful of job and leadership. With regard to demotivational factors, it is possible to note on the Czech side a higher importance of the relationship with the superior and the way of his management, which are replaced on the Slovak side by the sensuality of the work performed or the poor performance of the employee.

\section{DISCUSSION AND CONCLUSION}

The aim of the paper was to identify the factors that support the motivation or demotivation of the generation Z. A qualitative method of empathy-based stories (MEBS) was used for the research. The qualitative nature of the research aims, based on storytelling, to reveal possible hidden unique factors.

Based on the above outputs, it is clear that the identified motivational factors in the form of Meaningful work and Reward agree with the presented research (Gomez, Mawhinney \& Betts, 2018; Half, 2015; Wiedmer, 2015; Schawbel, 2014). However, discrepancies can be observed in the area of Co-workers (relationships with colleagues, atmosphere, etc.). Although research puts this factor first, these studies have not identified this factor as important. However, according to Kutlák (2020), the position of this factor is in line with the expectations of employers from the generation $\mathrm{Z}$. In the mentioned research, the factor Attractive workplace culture, respectively the area of Social and Corporate Atmosphere is according to HR managers one of the most important for individuals from the examined generation $\mathrm{Z}$.

According to ManpowerGroup (2016), Sidorcuka and Chesnoviska (2017) and Henley (2019), the needs of generation $\mathrm{Z}$ also include flexibility, which can relate both in terms of time and, for example, the performance of tasks. However, in the presented research, the item Work-time was mentioned in the positive story by $5 \%$ of respondents, in the negative by $6 \%$. Only 1 respondent mentioned the related issue of Work-life-balance in the positive story, none in the negative one. However, it should be noted that despite the fact that a large proportion $(90 \%)$ of respondents reported at least partial work experience, they are still university students with a median age of the sample of 21 years. It is therefore possible that the growing interest in this area will be possible to observe in the individuals only in connection with starting a job.

A similar limitation by the current status of respondents may also affect the position of the Achievement cluster, which includes career growth or personal development. Students often may not feel at present and therefore reflect the need for further education or development. This area makes up only $12 \%$ of the presented research, in contrast to the outputs according to Wiedmer (2015) or Schawbel (2014). According to Kutlák (2020), even the area of Education and Careers is or will be, based on the expectations of employers, the most important for the generation $\mathrm{Z}$.

Due to the fact that the MEBS method works on a qualitative basis, it is appropriate to subject the obtained results to quantitative verification, which can, based on deeper statistical processing, validate the presented results. The present research has certain limitations. First, as mentioned above, the size and nature of the sample is due to the fact that the outputs obtained cannot be generalized. Furthermore, the coding process of content analysis is slightly influenced by subjectivity, which may have an impact on the outputs or on the comparison of similar studies, despite the use of the same method of data collection. Finally, the data used are influenced by the age of the respondents, especially in the younger representatives of the generation $\mathrm{Z}$. 


\section{Acknowledgement}

This paper was created within the project SGS-2020-015 "Výzkum vybraných oblastí managementu a marketingu organizací v kontextu demografických a technologických změn".

\section{References}

Adecco. (2019). Millennials vs Gen Z: Key Differences: Adecco USA. Retrieved from https://www.adeccousa.com/employers/resources/generation-z-vs-millennialsinfographic/

Baldonado, A. M. (2018). Leadership and Gen Z: Motivating Gen Z Workers and Their Impact to the Future. International Journal of Managerial Studies and Research, 6(1), 56-60. doi: $10.20431 / 2349-0349.0601008$

Bencsik, A., Juhász, T., \& Horváth-Csikós, G. (2016). Y and Z Generations at Workplaces. Journal of Competitiveness, 6(3), 90-106. doi: 10.7441/joc.2016.03.06

Berkup, S. (2014). Working with Generations X and Y in Generation Z Period: Management of Different Generations in Business Life. Mediterranean Journal of Social Sciences, 19(5), 218-229. doi: 10.5901/mjss.2014.v5n19p218

Cision. (2013). Generation Z: A Look at The Technology and Media Habits of Today's Teens. Retrieved from https://www.prnewswire.com/news-releases/generation-z-a-look-atthe-technology-and-media-habits-of-todays-teens-198958011.html

Gomez, K, Mawhinney, T, \& Betts, K. (2018). Welcome to Generation Z. Retrieved from https://www2.deloitte.com/content/dam/Deloitte/us/Documents/consumerbusiness/welcome-to-gen-z.pdf

Eskola, J. (1991). The Use of the Method of Empathy-Based Stories in Social Research: A Technical Guide for Beginners. Tampere: University of Tampere.

Eurostat. (2020). Employment and Unemployment. Retrieved from https://ec.europa.eu/eurostat/en/web/lfs/statistics-illustrated

Fratričová, J., \& Kirchmayer, Z. (2018a). Barriers to work motivation of generation Z. Journal of Human Resource Management, 21(2), 28-39. Retrieved from https://www.jhrm.eu/2018/11/28-barriers-towork-motivation-of-generation-z/

Fratričová, J., \& Kirchmayer, Z. (2018b). What Motivates Generation Z at Work? Insights into Motivation Drivers of Business Students in Slovakia. Innovation Management and Education Excellence through Vision 2020, 6019-6030. Retrieved from https://www.researchgate.net/profile/Zuzana_Kirchmayer/publication/324797364_Wh at_Motivates_Generation_Z_at_Work_Insights_into_Motivation_Drivers_of_Business _Students_in_Slovakia/links/5b8e9796a6fdcc1ddd0e3430/What-MotivatesGeneration-Z-at-Work-Insights-into-Motivation-Drivers-of-Business-Students-inSlovakia.pdf

Friedrich, R., Peterson, M., Koster, A., \& Blum, S. (2010). The rise of Generation C: Implications for the world of 2020, Booz \& Company. Retrieved from https://www.strategyand.pwc.com/gx/en/insights/2002-2013/rise-generationc/strategyand-rise-of-generation-c.pdf

Gerace, A., Day, A., Casey, S., \& Mohr, P. (2013). An Exploratory Investigation of the Process of Perspective Taking in Interpersonal Situations. Journal of Relationships Research, 4(6), 1-12. doi: 10.1017/jrr.2013.6 
Half, R. (2015). The Secrets to Hiring and Managing Gen Z. Retrieved from https://www.roberthalf.com/research-and-insights/workplace-research/the-secrets-tohiring-and-managing-gen-z

Henley, D. (2019). How to Inspire and Motivate Your Gen Z Employees. Retrieved from https://www.forbes.com/sites/dedehenley/2019/07/11/how-to-inspire-and-motivateyour-gen-z-employees/

Hsieh, H. F., \& Shannon, S. (2005). Three Approaches to Qualitative Content Analysis. Qualitative Health Research, 15(9), 1277-1288. doi: 10.1177/1049732305276687

Issa, T., \& Isaias, P. (2016). Internet factors influencing generations $\mathrm{Y}$ and $\mathrm{Z}$ in Australia and Portugal: A practical study. Information, Processing \& Management, 52(4), 592-617. doi: 10.1016/j.ipm.2015.12.006

Koulopoulos, T., \& Keldsen, D. (2016). Gen Z effect: The six forces shaping the future of business. New York: Routledge.

Kultalahti, S., \& Viitala, R. L. (2014). Sufficient challenges and a weekend ahead - Generation Y describing motivation at work. Journal of Organizational Change Management, 27(4), 569-582. doi: 10.1108/JOCM-05-2014-0101

Kutlák, J. (2020). Expectations of Generation Z from Perspective of Employers: The Delphi Method. Proceedings of the 35th International Business Information Management Association Conference (pp. 5151-5161). King of Prussia, USA: IBIMA.

ManpowerGroup. (2016). Mileniálové a kariéra: Vize 2020. Retrieved from https://manpower.cz/media/milenialove.pdf

Merriman, M. (2015). What if the next big disruptor isn't a what but a who? Retrieved from https://www.ey.com/Publication/vwLUAssets/EY-rise-of-gen-znew-challenge-forretailers/\$FILE/EY-rise-of-gen-znew-challenge-for-retailers.pdf

Mičík, M., Tomczyk, Ł., Sládkayová, M., \& Varga, E. (2020). Social Media and Trust Building. Plzeň: Nava.

Monych, B. (2017). 3 no-nonsense tips for effectively managing Gen Z. Retrieved from https://www.insperity.com/blog/managing-gen-z/

Němečková, M. (2019). Lidí v produktivním věku bude ubývat. Retrieved from https://www.statistikaamy.cz/2019/02/lidi-v-produktivnim-veku-bude-ubyvat/

Posti-Ahokas, H. (2013). Empathy-based stories capturing the voice of female secondary school students in Tanzania. International Journal of Qualitative Studies in Education, 26(10), 1277-1292. doi: 10.1080/09518398.2012.731533

Schawbel, D. (2014). Gen Y and Gen Z Global Workplace Expectations Study. Retrieved from http://millennialbranding.com/2014/geny-genz-global-workplace-expectations-study/

Sidorcuka, I., \& Chesnovicka, A. (2017). Methods of Attraction and Retention of Generation Z Staff. $\quad C B U$ International Conference Proceedings, 5, 807-814. doi: 10.12955/cbup.v5.1030

Wallin, A., Koro-Ljungberg, M., \& Eskola, J. (2019). The method of empathy-based stories. International Journal of Research \& Method in Education, 42(5), 525-535. doi: 10.1080/1743727X.2018.1533937 
Wiedmer, T. L. (2015). Generations Do Differ: Best Practices in Leading Traditionalists, Boomers, and Generations X, Y, and Z. Delta Kappa Gamma Bulletin, 82(1), 51-58. Retrieved from https://search.proquest.com/docview/1770514324?accountid=15518

\section{Contact information}

\section{Ing. Jiří Kutlák}

University of West Bohemia, Faculty of Economics

Univerzitní 22, 30614, Plzeň, Czech Republic

E-mail: kutlak@kpm.zcu.cz

ORCID: 0000-0002-6866-6525

doi: 10.7441/dokbat.2020.27 